\title{
Pelatihan Produksi Hand Soap dan Hand Sanitizer dalam Penanggulangan Covid-19 di Pesantren Global Tarbiyyatul Arifin Desa Mangliawan Kabupaten Malang (Hand Soap and Hand sanitizer production training in Covid-19 Prevention at Global Tarbiyyatul Arifin Islamic Boarding School, Mangliawan Village, Malang Regency)
}

\author{
Sinar Perbawani Abrina Anggraini ${ }^{1}$, Ayu Chandra Kartika Fitri ${ }^{2 *}$, Fikka Kartika \\ Widyastuti $^{3}$ \\ ${ }^{1,2,3}$ Program Studi Teknik Kimia, Fakultas Teknik, Universitas Tribhuwana Tunggadewi Malang \\ *Email corresponding author: ayu.chandra@ unitri.ac.id ${ }^{2}$
}

\begin{abstract}
ABSTRAK
Desa Mangliawan adalah sebuah desa yang termasuk zona merah rentan tersebar virus Covid-19. Di desa Mangliawan terdapat pesantren Global Tarbiyyatul Arifin yaitu salah satu lembaga pendidikan Islam non formal bagi para santri. Kementrian Agama telah menghimbau salah satunya dengan surat edaran terkait amannya Covid-19, untuk memutuskan rantai penularan Covid-19 di lingkungan pondok pesantren. Sehingga pesantren Global Tarbiyyatul Arifin perlu menjalankan protokol kesehatan salah satunya dengan mencuci tangan dengan sabun di bawah air yang mengalir. Selain itu perlu juga untuk penggunaan cairan antiseptik pada kondisi di luar rumah di masa pandemi. Berdasarkan permasalahan tersebut, maka tim pengabdian masyarakat memberikan pelatihan cara membuat hand soap dan hand sanitizer supaya lebih mandiri dalam menanggulangi penyebaran Covid-19 di lingkungan pesantren. Selain diberikan pelatihan, mereka juga diberikan penyuluhan tentang cara menghindari penyebaran Covid-19 dan cara menjaga imun untuk menangkis virus corona. Hasil dari kegiatan ini, para penghuni pesantren dan masyarakat di sekitarnya semakin paham dan lebih bisa menjaga diri dengan membuat hand soap dan hand sanitizer secara mandiri dengan mudah.
\end{abstract}

Keywords: Covid 19, Hand Soap, Hand Sanitizer, Imun, Pesantren

\begin{abstract}
Mangliawan Village is a village in the red zone vulnerable to the spread of the Covid-19 virus. In Mangliawan village, there is the Global Tarbiyyatul Arifin Islamic boarding school, which is one of the non-formal Islamic education institutions for students. The Religion Ministry has urged one of them with a circular regarding the safety of Covid-19 to break the chain of Covid-19 transmission in the boarding school environment. The Global Tarbiyyatul Arifin Islamic boarding school needs to carry out health protocols, by washing hands with soap under running water. Also, it is necessary to use antiseptic fluids in outdoor conditions during a pandemic. Based on these problems, the community service team provided training on making hand soap and hand sanitizers to be more independent in overcoming the spread of Covid-19 in the pesantren environment. Besides training, they were also given counseling on how to avoid the spread of Covid-19 and how to maintain immunity to fend off the coronavirus. As a result of this activity, the pesantren and the surrounding community's residents understand more and protect themselves by making hand soap and hand sanitizer independently quickly.
\end{abstract}

Keywords: Covid 19, Hand Soap, Hand Sanitizer, Immune, Islamic Boarding School 


\section{PENDAHULUAN}

Informasi tentang bahaya dan proses penyebaran virus corona harus diberikan secara lengkap agar masyarakat dapat memahami secara utuh. Tidak utuhnya informasi terkait bahaya dan potensi penularan virus corona, dinilai menjadi faktor munculnya kasus baru. Sekitar 70\% masyarakat mengetahui tentang bahaya Covid-19 dan 85,33\% kasus masyarakat sebagian besar termasuk kategori kasus resiko rendah (Yanti, Nugraha, Wisnawa, Agustina, \& Diantari, 2020). Dalam rangka memutus rantai penularan virus corona yang mewabah saat ini, dilakukan tindakan-tindakan pencegahan Covid-19 di lingkungan pendidikan pondok pesantren. Langkah tersebut dilakukan untuk kebaikan semua pihak, terutama para santri, agar dapat belajar dengan nyaman, aman dan terhindar dari penularan virus Corona.

Pondok pesantren termasuk sulit untuk melakukan protokol kesehatan terutama dengan tidak menjaga jarak, lalai pemakaian masker dan kurang patuhi mencuci tangan setiap saat (Indarsih, 2020). Peminat para orang tua untuk memondokkan anaknya ke pondok pesantren naik dua kali lipat dan secara umum tidak memiliki fasilitas kesehatan yang memadai, sehingga berpotensi memunculkan klaster baru penyebaran Covid-19 di kalangan pondok pesantren (Indarsih, 2020).

Kementerian Agama telah menerbitkan surat edaran tentang tindaklanjut protokol kesehatan, setelah terbitnya SKB (Surat Keputusan Bersama) empat menteri terkait panduan penyelenggaraan pembelajaran tahun ajaran 2020/2021 di masa pandemi. Di masa pandemic ini, pembelajaran dihimbau dilakukan dengan memanfaatkan media e-learning secara daring. Namun untuk pesantren, pembelajaran secara daring dianggap kurang efektif. (Wijaya Mustika; Yadewani, Dorris, 2020)

Direktur Pendidikan Diniyah dan Pondok Pesantren, Dr. H. Waryono, M.Ag melalui media online menyampaikan beberapa pesantren sudah menerapkan sikap disiplin dalam penerapan protokol kesehatan bagi para santri, yaitu dengan mendatangkan santrinya secara bertahap, penyediaan ruang isolasi khusus dan melaksanakan rapid test kepada para santri. Kemudian diberlakukan juga syarat-syarat sebelum masuk pondok, santri wajib memberikan surat keterangan sehat dari instansi kesehatan (puskesmas) dan wajib dikarantina/isolasi selama empat belas hari sebelum ikut pembelajaran di pesantren. Dari seluruh pondok pesantren yang ada, hanya tiga puluh persennya yang siap dalam pencegahan Covid-19. Ketidaksiapan tersebut disebabkan karena belum tersedianya sarana dan prasarana yang memadai di pesantren tersebut. Namun ketika ada santri yang terkonfirmasi positif virus 
Covid-19, pesantren baru menempuh berbagai protokol kesehatan. Hal tersebut disampaikan dalam diskusi Gugus Tugas Nasional di Graha BNPB, Jakarta, Selasa (21/7/2020). (Sumeks.co, 2020)

Ditambah lagi arus informasi yang beredar tentang wabah virus corona baik yang fakta maupun hoaks melalui media sosial dan media online dapat diakses dengan cepat dan fleksibel oleh masyarakat awam, sehingga mengakibatkan kebingungan di tengah masyarakat (Nurnawati \& Arbintarso, 2021). Hal ini yang kemudian mendorong untuk melakukan penyuluhan mengenai fakta wabah virus corona kepada masyarakat.

Kegiatan Pengabdian Masyarakat ini merupakan salah satu bentuk kepedulian Perguruan Tinggi pada masyarakat untuk berpartisipasi dalam memecahkan problematika kemasyarakatan khususnya di tahun 2020 ini terkait penanganan pandemi Covid-19. Pengabdian ini difokuskan pada lembaga pendidikan yang berbentuk pondok pesantren dan masyarakat muslim secara umum. Sehingga, diharapkan kelompok santri ini dapat menjadi contoh sekaligus pengawas dari rekan-rekannya agar terus konsisten menerapkan disiplin protokol kesehatan di lingkungan pondok pesantren, termasuk di lingkungan masyarakat sekitarnya. Dalam rangka tindakan preventif menghadapi pandemi covid-19 saat ini, maka tim pengabdian masyarakat melakukan edukasi terkait bahaya virus covid-19,

Program mencuci tangan dengan menggunakan sabun yang dilakukan secara bersamaan dapat menjalankan program pemerintah untuk memutus rantai penularan Covid19. Secara tidak langsung tangan akan sering bersentuhan pada permukaan benda atau apapun karena tangan merupakan media transmission Covid-19 terhadap mata, hidung dan mulut (Purnama \& Susanna, 2020). Untuk menghindari penularan Covid-19, maka perlu adanya program pencucian tangan dengan menggunakan sabun berupa handsoap sebelum menyentuh benda, mulut, hidung dan mata. Penggunaan sabun untuk mencuci tangan yang baik adalah berupa sabun cair (Kholil, 2020). Jadi sangat tepat jika dilakukan pelatihan pembuatan handsoap sebagai salah satu program pencegahan penularan virus corona untuk para santri di pesantren Global Tarbiyyatul Arifin.

Pemakaian program hand soap dapat digunakan di sekitar rumah atau di dalam rumah. Untuk pamakaian di luar rumah, maka penggunaan praktis adalah dengan penggunaan hand sanitizer. Namun harga untuk hand sanitizer mahal, maka sangat lebih ekonomis jika dapat dibuat sendiri. Sesuai dengan rekomendasi dari World Health Organization (WHO) bahwa memakai cairan antiseptik adalah salah satu cara yang utama 
untuk pencegahan penyebaran virus corona (Sundari, Taher, Nurhasanah, Mas'ud, \& Hasan, 2020)

Pembinaan penerapan disiplin protokol kesehatan untuk menghindari adanya penularan virus corona dimasa pandemi saat ini, perlu diadakan pelatihan pembuatan hand soap dan hand sanitizer kepada pengurus, pengajar, para santri di Pesantren Global Tarbiyyatul Arifin serta perwakilan warga setempat.

Pembuatan hand soap dan hand sanitizer disesuaikan dengan standarisasi organisasi kesehatan dunia (WHO) untuk dapat dimanfaatkan para santri di lingkungannya, sehingga saat dibutuhkan mereka tidak perlu lagi membeli, karena telah mampu membuatnya secara mandiri. Dari kegiatan ini diharapkan dapat terbentuk sebuah sistem yang kokoh dan saling menguatkan bersama-sama mencegah potensi terbentuknya klaster baru di lingkungan Desa Mangliawan, Kecamatan Pakis, Kabupaten Malang.

\section{METODE PELAKSANAAN}

Metode yang dipakai dalam kegiatan pengabdian masyarakat ini, yaitu dengan penyuluhan, pendampingan, dan pelatihan. Pelaksanaan kegiatan ini dilakukan pada bulan Agustus 2020 oleh tim pengabdi yang terdiri dari dosen UNITRI dan mahasiswa UNITRI. Letak lokasi kegiatan ini ada di Pesantren Global Tarbiyyatul Arifin, Desa Mangliawan. Desa Mangliawan adalah salah satu desa yang terletak di Kecamatan Pakis, wilayah Kabupaten Malang.

Pelatihan dan pendampingan yang diberikan kepada para santri, pengajar dan pengurus pesantren serta perwakilan warga sekitar adalah pembuatan hand soap dan hand sanitizer. Selain itu memberikan penyuluhan tentang mengenal dan mewaspadai Covid-19, mengetahui gejala gejala yang ditimbulkan Covid-19, melakukan pencegahan Covid-19 sejak dini serta memberikan rekaman video pembuatan hand soap dan hand sanitizer. Tahapan kegiatan pengabdian masyarakat yang dilakukan meliputi pendidikan masyarakat, pelatihan/training pembuatan hand soap dan hand sanitizer, dan simulasi iptek (simulasi produk) yang diuraikan sebagai berikut :

- Pendidikan Masyarakat

Pada kegiatan ini dilakukan penyuluhan dengan memberikan pengetahuan antara lain mengenal dan mewaspadai Covid-19, mengetahui gejala gejala yang ditimbulkan 
Covid-19, melakukan pencegahan Covid-19 sejak dini serta memberikan tayangan video motivasi untuk benar-benar menjaga diri dari hal-hal yang berpotensi menimbulkan penyakit. Hal ini perlu dilakukan supaya para santri sadar sepenuhnya tentang bahayanya virus corona di masa pandemi dengan selalu peduli pada protokol kesehatan sehingga diharapkan tidak akan muncul klaster baru di kalangan pesantren.

○ Pelatihan

Dalam rangka tindakan preventif menghadapi pandemi Covid-19 saat ini, maka masyarakat Desa Mangliawan, khususnya para santri di Pesantren Global Taribyatul Arifin diberikan pelatihan cara pembuatan hand soap dan hand sanitizer sebagai salah satu pencegahan virus corona. Bahan yang digunakan mudah didapatkan di toko kimia dengan cara dicampur dengan motor pengaduk yang sederhana.

○ Simulasi Ipteks

Pada kegiatan ini dilakukan simulasi dengan memberikan hasil hand soap dan hand sanitizer serta mengaplikasikan langsung kepada para santri dan perwakilan warga sekitar. Para santri merasa terbantukan dengan adanya hand soap dan hand sanitizer. Mereka menyambut dengan senang hati adanya bantuan kegiatan pelatihan yang dilakukan oleh tim pengabdi ini.

\section{HASIL DAN PEMBAHASAN}

Kegiatan pengabdian masyarakat ini dihadiri oleh 6 orang pengurus pesantren, 10 orang santri dan 3 orang perwakilan dari warga sekitar. Dalam kegiatan ini dilakukan penyuluhan, pelatihan dan pendampingan yang berfokus pada pencegahan virus corona. Diharapkan dari kegiatan ini dapat berkelanjutan melalui pelatihan yang telah diberikan oleh tim pengabdi. Pelatihan yang dilaksanakan yaitu pembuatan hand soap dan hand sanitizer. Sesuai dengan anjuran dari pemerintah untuk selalu menjaga kebersihan dengan sering mencuci tangan dengan bersih menggunakan sabun. Sabun merupakan salah satu kelemahan dari virus corona mudah mati sehingga disarankan untuk sering mencuci tangan menggunakan air yang mengalir. WHO merekomendasikan untuk mencegah penularan virus corona adalah mencuci tangan menggunakan sabun dan mendesinfeksi permukaan benda yang sering digunakan (Purnama \& Susanna, 2020). Di Indonesia kesadaran untuk mencuci tangan masih rendah. Oleh karena itu tim pengabdi merasa berkewajiban untuk memberikan pengetahuan dan pelatihan pembuatan hand soap yang nantinya akan dapat digunakan dan dibuat secara mandiri dan berkelanjutan. 
Berikut prosedur pembuatan hand soap dan hand sanitizer:

\section{a. Pembuatan Handsoap}

Bahan-bahan yang diperlukan untuk membuat handsoap diantaranya SLES (Sodium Lauryl Sulphate), natrium klorida/garam industri, benzalkonium klorida sebagai anti mikroorganisme, CAPB (Cocamidopropyl betaine), aquades, dan parfum. Semua bahan ditambahkan satu per satu kemudian diaduk merata secara manual atau menggunakan alat pengaduk. Cairan handsoap didiamkan selama semalam sehingga berwarna jernih kemudian dikemas.

\section{b. Pembuatan Handsanitizer}

Langkah pertama adalah menyiapkan bahan-bahan seperti ethanol 96\%, gliserol, hidrogen peroksida, aquades dan parfum. Mula-mula masukkan ethanol ke dalam beaker glass atau erlenmeyer. Tambahkan hidrogen peroksida kemudian gliserol, aduk hingga homogen menggunakan pengaduk kaca. Kemudian diencerkan menggunakan aquades hingga volume maksimum, tambahkan parfum secukupnya dan diaduk kembali. Jika sudah tercampur sempurna, uji kadar ethanol pada hand sanitizer tersebut menggunakan alkohol meter, dimana batas minimum alkohol dalam hand sanitizer adalah lebih dari sama dengan $70 \%$. Jika sudah memenuhi standar maka hand sanitizer dikemas dalam botol semprot dan siap digunakan.

Pada Gambar 1 memperlihatkan hasil pelatihan pembuatan hand soap yang diaplikasikan langsung kepada perwakilan warga sekitar. Beberapa warga melakukan testimoni untuk merasakan hasil pembuatan hand soap bersama beberapa santri dan pengurus pesantren serta pengajar pesantren. Hand soap yang digunakan ada beberapa varian aroma buah-buahan segar yang nyaman untuk dicium setelah mencuci tangan dengan bersih. 


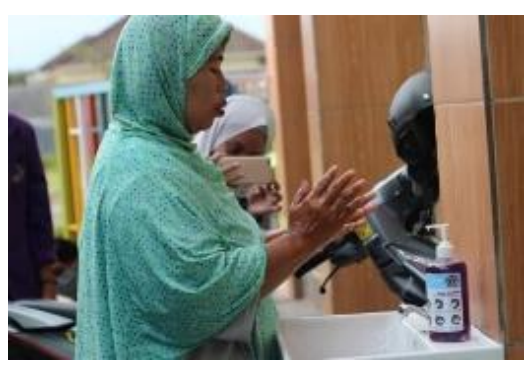

Gambar 1. Testimoni warga sekitar mencuci tangan dengan hand soap

Pada pembuatan hand soap mengandung triclosan yang dapat menghambat pertumbuhan bakteri. Dalam hal ini hand soap berperan penting untuk membunuh virus corona sehingga pencegahan penularan covid-19 dapat ditanggulangi (Marhamah, Ujiani, \& Tuntun, 2019). Untuk memenuhi rekomendasi dari WHO tentang penggunaan cairan antiseptik, maka tim pengabdi juga memberi pelatihan pembuatan hand sanitizer yang digunakan saat di luar rumah, sehingga akan tetap terjaga kebersihannya saat berada diluar rumah. Ditunjukkan pada Gambar 2 hasil pelatihan pembuatan hand sanitizer diaplikasikan langsung kepada pengurus pesantren.

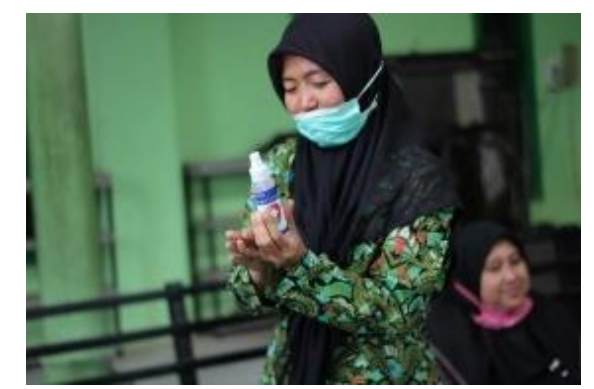

Gambar 2. Testimoni pengurus pesantren menggunakan hand sanitizer

Dengan penggunaan hand sanitizer sangat bermanfaat sebagai pelindung dan pelembut kulit (Nakoe, Lalu, \& Mohamad, 2020). Hand sanitizer terdapat kandungan alkohiol yang berfungsi sebagai anti mikroba dan terdapat emolien seperti gliserin, glisol propelin atau sorbitol yang mempunyai peran menjaga dan menghaluskan kulit (Nakoe et al., 2020). Walaupun sudah menggunakan hand sanitizer tetap dianjurkan untuk mencuci tangan menggunakan sabun. Hand sanitizer sifatnya hanya sementara, digunakan saat berada di luar rumah supaya lebih praktis dan bisa dibawa kemana-mana tanpa membutuhkan sabun dan air.

Pada Gambar 3 menunjukkan tim pengabdi juga memberikan beberapa penyuluhan untuk menambah pengetahuan tentang bahayanya covid-19 jika protokol kesehatan diabaikan dan tidak disiplin dalam menjalankannya. Pengetahuan tentang menhgenal beberapa gejala bagi yang terkena covid-19, sehingga lebih dini dapat dicegah dari awal. 


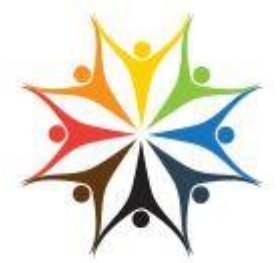

\section{Jurnal Berdaya Mandiri}

Vol. 3 No. 1 Tahun 2021

E-ISSN: 2685-8398

Mengkonsumsi makanan yang bergizi dan vitamin-vitamin yang dibutuhkan oleh tubuh untuk menghindari penularan virus corona. Harus tetap jaga kebugaran tubuh dengan mengkonsumsi sayuran dan buah-buahan segar untuk kebutuhan penangkal virus corona yang akan masuk kedalam tubuh manusia.

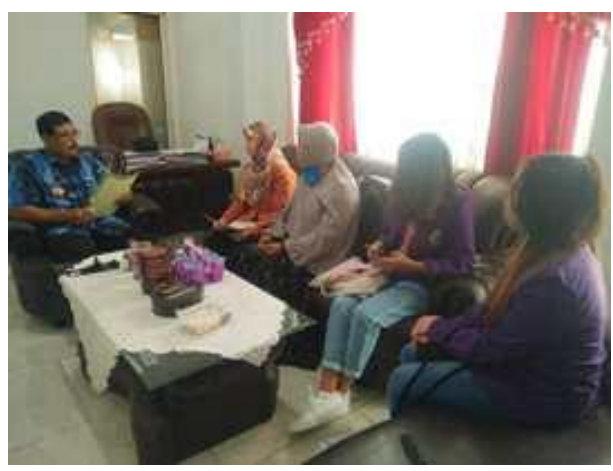

3a.

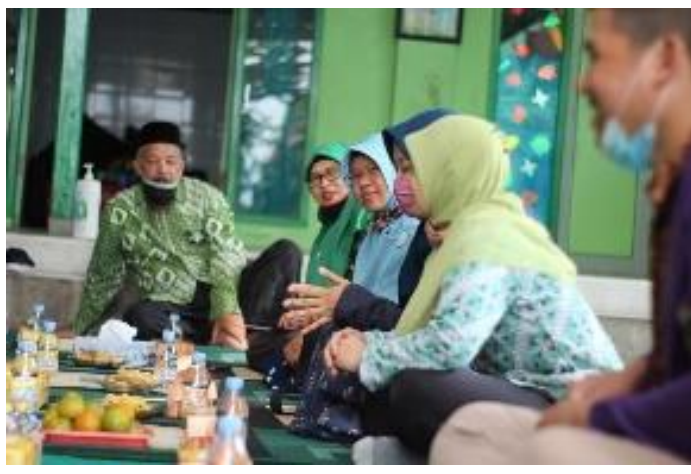

$3 b$

Gambar 3. a. Meminta perijinan kepada Kepala Desa Mangliawan, Kecamatan Pakis

b. Memberikan penyuluhan kepada para santri, pengajar, dan pengurus Pesantren Global Tarbiyyatul Arifin serta perwakilan warga sekitar

Dalam kegiatan beberapa pelatihan pembuatan hand soap dan hand sanitizer dilaksanakan dengan para santri dan beberapa warga sekitar untuk mahir dalam pembuatan secara mandiri seperti pada Gambar 4.
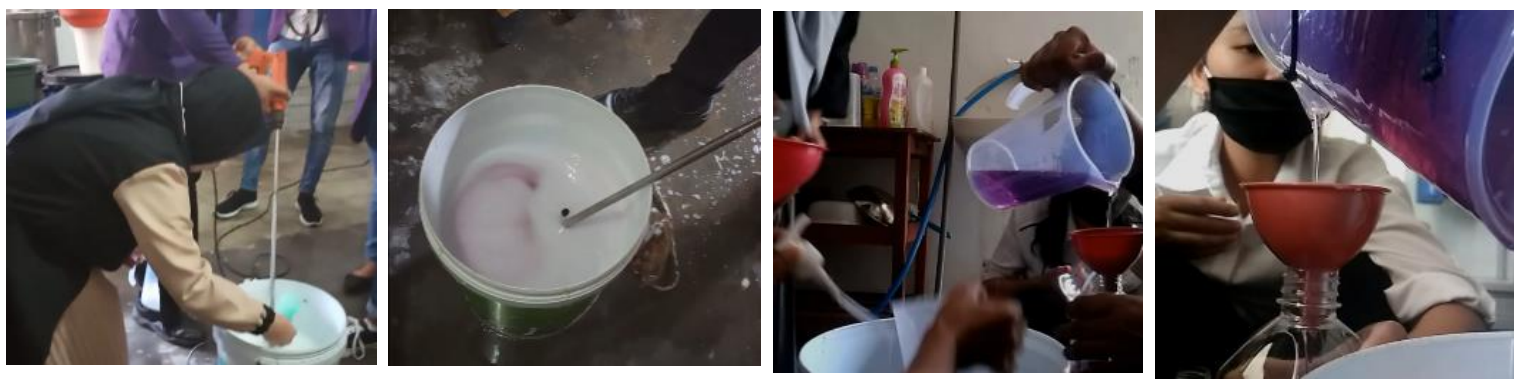

Gambar 4a. Pelatihan pembuatan hand soap
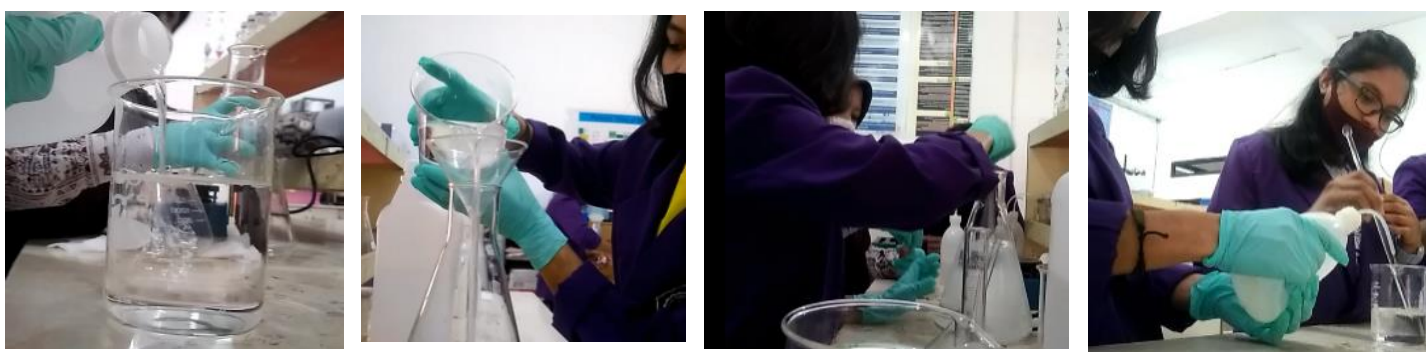

Gambar 4b. Pelatihan pembuatan hand sanitizer 
Pada Gambar 4 dalam pelaksanaan pelatihan pun tetap menggunakan protokol kesehatan dengan menjaga jarak dan memakai masker serta mencuci tangan ketika masuk pesantren. Pada pelaksanaan pelatihan tersebut tidak semua ikut karena mengingat luas ruang tidak memadai untuk diisi orang banyak.

Pada Gambar 5 menunjukkan kegiatan serah terima produk hand soap dan hand sanitizer dilakukan bersama pengurus dan tim pengabdi beserta beberapa mahasiswa UNITRI.
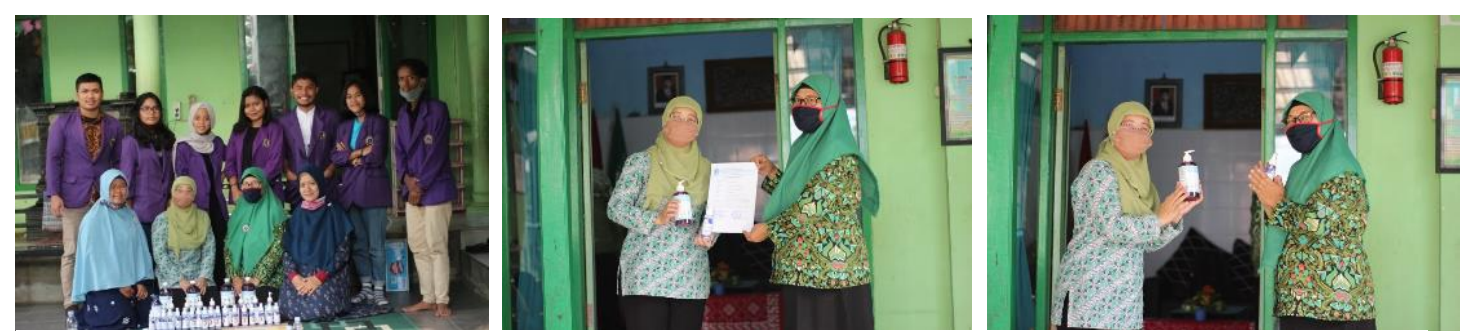

Gambar 5. Pemberian berita acara penyerahan produk hand soap dan hand sanitizer

Pada kegiatan pengabdian masyarakat ini merupakan program yang berkelanjutan dengan harapan warga sekitar khususnya warga pesantren dapat membuat secara mandiri produk yang telah dibuat dengan melihat tayangan video cara pembuatan hand soap dan hand sanitizer jika mereka lupa cara pembuatannya.

\section{KESIMPULAN}

Meningkatnya pemahaman pengurus pesantren terkait bahaya Covid-19 dan lebih bersikap disiplin dalam menerapkan protocol kesehatan. Produk ini dapat diterima dan digunakan oleh warga pesantren dan warga sekitar serta dapat membuat hand soap dan hand sanitizer secara mandiri (tanpa perlu membeli). Pendistribusian produk hand soap dan hand sinitzer ke warga pesantren serta warga sekitar mampu membantu pencegahan penyebaran virus Covid-19.

\section{UCAPAN TERIMAKASIH}

Tim pengabdi mengucapkan terima kasih kepada pihak institusi (LPPM UNITRI) yang telah memfasilitasi dan mendanai jalannya kegiatan pengabdian ini. Tim pengabdi juga mengucapkan terima kasih kepada pihak pesantren yang ikut berpartisipasi dalam menjalankan kegiatan ini serta memberikan fasilitas tempat sehingga kegiatan dapat berjalan lancar sesuai dengan jadwal dan rencana. 


\section{Jurnal Berdaya Mandiri}

Vol. 3 No. 1 Tahun 2021

E-ISSN: 2685-8398

\section{DAFTAR PUSTAKA}

Indarsih, F. (2020). Covid-19 dan Tantangan Reformasi Pondok Pesantren. Jurnal Ilmu Pendidikan Dan Pembelajara, 3(1), 79-90.

Kholil, M. (2020). Utilization of Bar Soap (Sabbath) Becomes Liquid Hand Soap to Prevent the Spread of Covid-19 (Community Service in Singocandi Village, City District, Kudus Regency). In Seminar Nasional Manajemen Bencana PSB (pp. 382 - 386). Solo: UNS.

Marhamah, Ujiani, S., \& Tuntun, M. (2019). Kemampuan Sabun Antiseptik Cair yang Mengandung Triclosan yang Terdaftar di BPOM dalam Menghambat Pertumbuhan Bakteri Escherichia coli. Jurnal Kesehatan, 10(1), 17-26.

Nakoe, M. R., Lalu, N. A. S., \& Mohamad, Y. A. (2020). PERBEDAAN EFEKTIVITAS HAND-SANITIZER DENGAN CUCI TANGAN MENGGUNAKAN SABUN SEBAGAI BENTUK PENCEGAHAN COVID-19. Jambura Journal of Health Sciences and Research, 2(2), 65-70.

Nurnawati, E. K., \& Arbintarso, E. S. (2021). SIKAP MASYARAKAT TERHADAP ARUS INFORMASI DI MASA PANDEMI COVID 19: KEGIATAN PENYULUHAN KEPADA PERSATUAN WANITA DARUSSALAM (PWD). Jurnal Berdaya Mandiri, 3(1), 419-428. https://doi.org/https://doi.org/10.31316/jbm.v3i1.998

Purnama, S. G., \& Susanna, D. (2020). Hygiene and Sanitation Challenge for COVID-19 Prevention in Indonesia. Jurnal Kesehatan Masyarakat Nasional, (1), 6-13.

Sumeks.co. (2020). Bagaimana Pencegahan Covid-19 di Pondok Pesantren. Sumeks.Co. Retrieved from https://sumeks.co/bagaimana-pencegahan-covid-19-di-pondokpesantren/

Sundari, Taher, D. M., Nurhasanah, Mas'ud, A., \& Hasan, S. (2020). Pendampingan pembuatan hand sanitizer berbasis kearifan lokal (ekstrak tangkai bunga cengkeh). ABSYARA: Jurnal Pengabdian Pada Masyarakat, 1(2), 15-21.

Wijaya Mustika; Yadewani, Dorris, R. L. (2020). DAMPAK PANDEMI COVID19 TERHADAP PEMANFAATAN E LEARNING. JURNAL DIMENSI.

Yanti, N. P. E. D., Nugraha, I. M. A. D. P., Wisnawa, G. A., Agustina, N. P. D., \& Diantari, N. P. A. (2020). GAMBARAN PENGETAHUAN MASYARAKAT TENTANG COVID-19 DAN PERILAKU MASYARAKAT DI MASA PANDEMI COVID-19. Jurnal Keperawatan Jiwa, 8(3), 485-490. 